\title{
Self-care among people with Diabetes Mellitus and quality of care in Primary Health Care
}

\author{
Autocuidado entre pessoas com Diabetes Mellitus e qualidade do cuidado na Atenção Básica \\ Autocuidado entre personas con Diabetes Mellitus y la calidad de la atención en Atención Primaria de Salud
}

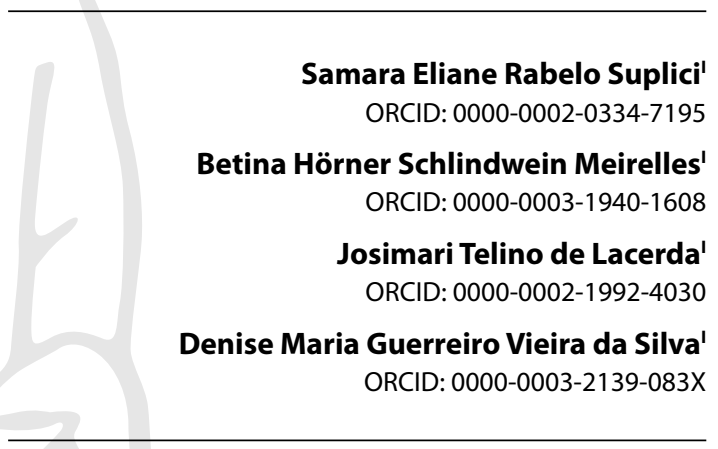

'Universidade Federal de Santa Catarina. Florianópolis, Santa Catarina, Brazil.

How to cite this article: Suplici SER, Meirelles BHS, Lacerda JT, Silva DMGV. Self-care among people with Diabetes Mellitus and quality of care in Primary Health Care. Rev Bras Enferm. 2021;74(2):e20200351. https://doi.org/10.1590/0034-7167-2020-0351

Corresponding author:

Samara Eliane Rabelo Suplici E-mail: samara.suplici@gmail.com

EDITOR IN CHIEF: Dulce Barbosa ASSOCIATE EDITOR: Hugo Fernandes

Submission: 06-22-2020

Approval: $12-06-2020$

\begin{abstract}
Objectives: to verify the adherence to self-care activities among people with diabetes mellitus and its association with quality of care received in Primary Care. Methods: a cross-sectional study with 329 people with diabetes assisted in Primary Care. Sociodemographic and self-care data were collected. To assess quality of care in Primary Care, secondary data from the Access and Quality Improvement Program were used. For comparisons between adherence to selfcare activities and quality of care received in Primary Care, the Kruskal-Wallis Test was used. Results: better adherence to the diet, blood glucose monitoring and medication use were observed among people with diabetes treated in Primary Care with better coordination of care, agenda organization, and equipment. Foot examination, despite the inverse relationship with quality of care, proved to be desirable. Conclusions: adherence to self-care among people with diabetes was associated with quality of care received in Primary Care.
\end{abstract}

Descriptors: Self Care; Diabetes Mellitus; Primary Health Care; Health Evaluation; Nursing Care.

\section{RESUMO}

Objetivos: verificar a adesão às atividades de autocuidado entre pessoas com diabetes mellitus e sua associação com a qualidade do cuidado recebido na Atenção Básica. Métodos: estudo transversal com 329 pessoas com diabetes atendidas na Atenção Básica. Coletaram-se dados sociodemográficos e referentes ao autocuidado. Para avaliar a qualidade do cuidado na Atenção Básica, foram utilizados dados secundários do Programa Melhoria do Acesso e da Qualidade. Para comparações entre adesão às atividades de autocuidado e qualidade do cuidado recebido na Atenção Básica, foi utilizado Teste Kruskal-Wallis. Resultados: melhor adesão à dieta, monitoramento glicêmico e uso dos medicamentos foram observados entre pessoas com diabetes atendidas na Atenção Básica com melhor coordenação do cuidado, organização da agenda e equipamentos. O exame dos pés, apesar da relação inversa com a qualidade do cuidado, mostrou-se desejável. Conclusões: a adesão ao autocuidado entre pessoas com diabetes se associou à qualidade do cuidado recebido na Atenção Básica. Descritores: Autocuidado; Diabetes Mellitus; Atenção Primária à Saúde; Avaliação em Saúde; Cuidados de Enfermagem.

\section{RESUMEN}

Objetivos: verificar la adherencia a las actividades de autocuidado en personas con diabetes mellitus y su asociación con la calidad de la atención recibida en Atención Primaria. Métodos: estudio transversal con 329 personas con diabetes atendidas en Atención Primaria. Se recogieron datos sociodemográficos y de autocuidado. Para evaluar la calidad de la atención en Atención Primaria se utilizaron datos secundarios del Programa de Mejora de Acceso y Calidad. Para las comparaciones entre la adherencia a las actividades de autocuidado y la calidad de la atención recibida en Atención Primaria se utilizó la prueba de Kruskal-Wallis. Resultados: se observó mejor adherencia a la dieta, seguimiento glucémico y uso de medicamentos en personas con diabetes atendidas en Atención Primaria con mejor coordinación de la atención, organización de la agenda y equipamiento. El examen de los pies, a pesar de la relación inversa con la calidad de la atención, resultó ser deseable. Conclusiones: la adherencia al autocuidado en personas con diabetes se asoció con la calidad de la atención recibida en Atención Primaria.

Descriptores: Autocuidado; Diabetes Mellitus; Atención Primaria de Salud; Evaluación en Salud; Atención de Enfermería. 


\section{INTRODUCTION}

Diabetes mellitus (DM) is one of the most prevalent non-communicable chronic diseases worldwide ${ }^{(1-2)}$. Treatment requires complex measures involving diet modification, incorporation of physical activity, continuous use of medications, blood glucose monitoring and foot care. There is sufficient evidence that these self-care activities when incorporated into the lives of people with DM are able to maintain glycemic control and reduce the risk of complications arising from the disease ${ }^{(2-3)}$.

Despite the benefits associated with self-care, membership in these activities remains relatively low $^{(4-5)}$. This represents a great demand for the public health system, particularly for Primary Care, which is one of the most important sources for people with DM to develop self-care strategies ${ }^{(2)}$.

Adherence to self-care activities among people with DM can be influenced by a number of individual, social and health system-related factors. In this sense, one of the greatest challenges of the health system is that Primary Care improves quality of health care for people with DM and avoids complications resulting from the disease by ensuring access, resolution, and comprehensiveness ${ }^{(6)}$.

Primary Care organization in Brazil takes place through the Family Health Strategy (FHS), operationalized through the implementation of multidisciplinary health teams in Basic Health Units (BHU) in the community. The relationship between people with DM and Primary Care is an important element for the success in adopting self-care behaviors ${ }^{(7)}$.

National and international studies on the subject highlight the importance of quality of primary care services as a strategy to improve self-care among people with $\mathrm{DM}^{(5-7)}$. These studies indicate that although Primary Care is fulfilling its role with regard to macrostructural issues, such as the incorporation of FHS in caring for people with DM, there are many microstructural weaknesses in the care of these people that can compromise self-care ${ }^{(6-7)}$.

Therefore, these same studies recommend other studies that may evidence which aspects of quality of care in Primary Care are associated with self-care among people with $\mathrm{DM}^{(5-7)}$. This knowledge gap, i.e., if the quality care provided results in an improvement in self-care among people with DM, motivated this study. Understanding the relationship between self-care and quality of care received in Primary Care is necessary for health professionals to have measures to assess their work.

Thus, the research question is: what is the association between the association with self-care activities in people with DM and quality of care received in Primary Care?

The hypothesis is that people with DM who receive better quality care in Primary Care have better access to self-care activities.

\section{OBJECTIVES}

To verify the adherence to self-care activities among people with diabetes mellitus and its association with quality of care received in Primary Care.

\section{METHODS}

\section{Ethical aspects}

This study followed the ethical aspects of research with human beings, according to Resolution 466/2012 of the Brazilian National Health Council (Conselho Nacional da Saúde), being approved by the Research Ethics Committee of Universidade Federal de Santa Catarina.

\section{Study design, period, and location}

This is a descriptive study with quantitative approach ${ }^{(8)}$, written according to STROBE recommendation, conducted in four BHU of a median-sized municipality of Santa Catarina, Brazil, from January to June 2017. Among the $19 \mathrm{BHU}$ that are part of the Primary Care of that municipality, two BHU were selected with better assessed FHS teams and two BHU with worst-rated FHS teams assessed in their overall performance, according to the Program for Improving Access and Quality of Primary Care (PMAQ-AB - Programa de Melhoria do Acesso e da Qualidade da Atenção Básica). This program assesses FHS teams in order to improve quality of Primary Care ${ }^{(9)}$. In assessment, quality standards organized in dimensions that assess the structure and work process of FHS teams are verified, each of which has specific subdimensions.

After the assessment process, FHS teams are classified into four categories: poor performance, median or below average, above average, and well above average. Teams receive an overall performance assessment and in assessment subdimensions ${ }^{(9)}$.

Thus, the criterion for defining the BHU participating in this study was based on the overall performance of FHS teams in the PMAQ-AB. BHU with the best evaluated teams should have at least two FHS teams and all of them with an overall performance "well above average". The worst assessed should have at least two FHS teams, with at least one "below average". It was an exclusion criterion to have teams rated "well above average". There were no teams with poor performance in the municipality in question.

\section{Population/sample; inclusion and exclusion criteria}

The population was composed of 1,314 people with DM registered in the four selected BHU. For the sample calculation, a 95\% confidence interval and a $50 \%$ prevalence were used. A prevalence of $50 \%$ was adopted due to the variability of adherence for each item of the Self-Care Activities Questionnaire used in data collection. After the calculation, the minimum sample size was 297 people.

Thus, the sample of this study was 329 people with DM, stratified according to the number of people with DM registered in each FHS team. The calculations were made on the Website SEstatNet ${ }^{\circ}$ / UFSC ${ }^{(10)}$. The sample was intentional, because it was desired to interview the people who actually use the $\mathrm{BHU}$ in question.

The criteria for inclusion of the participants were: being users of the selected $\mathrm{BHU}$, being over 18 years old, having DM for more than 01 year, having type 2 diabetes mellitus (DM2). Regarding the exclusion criteria, pregnant women and bedridden people who were unable to carry out self-care activities were questioned in the instrument. 
This study included 187 (56.8\%) people from five teams assessed as "well above average" in general performance, 82 (24.9\%) people from three teams assessed as "above average" and 60 (18.2\%) people from two teams rated "average or below average".

\section{Study protocol}

The outcome variable was Diabetes Self-Care - obtained from the Diabetes Self-Care Activities Questionnaire (QAD). The validated version of the Summary of Diabetes Self-Care Activities (SDSCA) instrument $^{(11)}$ is a measure of self-reported self-care activities in people with DM. It was decided to apply it in the form of an interview due to the difficulty of reading/visual of many of the participants. We chose to apply it in the form of an interview due to the reading/ visual difficulties of many of the participants. The instrument asks the person with DM to remember their self-care behaviors during the previous 7 days for six dimensions: general food (two items), specific food (three items), physical activity (two items), blood glucose monitoring (two items) items), foot care (three items) and medication use (three items, but a person answers one of them depending on type of treatment). The assessment is standardized on days of the week (zero to seven) and for each item that makes up the dimensions, the average number of days is calculated, with zero corresponding to the least desirable situation and seven to the most desirable situation. In the items of the dimension"specific food" on the consumption of foods rich in fat and consumption of sweets, the values were inverted $(7=0,6=1,5=2,4=3,3=4,2=5,1=6$, $0=7$ ), as recommended in the QAD. Smoking assessment is coded separately and has not been worked on in this article. Although the QAD does not provide a score for adherence to self-care activities, this study considered, for analysis, that the most desirable was that the person had followed the recommendations of each item for at least five days a week, based on studies previous ${ }^{(12-13)}$.

For the exposure variables, those related to the quality of care in Primary Care were considered. Secondary data obtained from the PMAQ available at the time of data collection were used. These data were made available by the municipality of that municipality and used as a measure of quality of care provided in Primary Care. Among the various dimensions of the PMAQ, the overall performance of the FHS teams was considered for analysis in this study, and specifically the sub-dimensions of the assessment that include actions aimed at chronic diseases ${ }^{(9)}$, namely: Organization of Primary Care team's agenda; Coordination of care in the care and resolution network; Equipment, materials, supplies and printed matter in the Health Unit; Basic pharmacy component drugs. Both the overall performance of the teams and each of these sub-dimensions have a rating:"well above average", "above average" or "below average", as already mentioned. These subdimensions were considered as a measure to assess the quality of care provided to people with DM in Primary Care.

Sociodemographic and clinical variables were also collected using a structured instrument with variables: age group (up to 59 years, 60-69 years, 70 years or more); sex (male, female); marital status (married, single, separated/divorced, widowed); income in minimum wages (less than 01, from 01 to 03 , from 03 to 06 , more than 06); years of education (never studied, from 01 to 05 years, from 06 to 09 years, from 10 to 12 years, 13 years or more); occupational situation (active, on sick leave, retired, unemployed); disease time (from 01 to 05 years, from 06 to 10 years, from 11 to 20 years, more than 20 years); type of drug treatment (oral hypoglycemic agents, oral hypoglycemic agents + insulin therapy, insulin therapy); use of other health services by insurance and/or individuals (yes or no); types of services used in BHU (medical consultations: yes or no, nursing consultations: yes or no, appointment of exams: yes or no, take medications: yes or no); frequency of $\mathrm{BHU}$ use (once a year, twice a year, three times a year, more than three times a year).

Invitation letters were sent to people with DM through community health agents and those who agreed to participate had the interview for data collection scheduled at $\mathrm{BHU}$ or residence, according to their availability.

Participants were informed about the research by the researchers. Participants signed the Informed Consent Term. The interviews at $\mathrm{BHU}$ were conducted individually in the office and the interviews at the person's residence eventually had the presence of a family member, who was instructed not to interfere with the answers.

The interviews were conducted by the main researcher and a student of an undergraduate course in nursing (previously trained to conduct the interviews) until the minimum number of the sample proportionally stratified for each FSF team was reached.

Data were collected from January to June 2017. The average time for each interview was 20 minutes.

\section{Analysis of results, and statistics}

The data were organized in a spreadsheet in Excel ${ }^{\circ}$, with double typing, performed by the main researcher and by a student of an undergraduate course in nursing. The analyzes were performed with the help of a professional specialized in statistics using IBM ${ }^{\circ}$ SPSS software, version 20.0. Descriptive statistics were calculated as means and standard deviations. Data distribution was assessed using the Kolmogorov-Smirnov test. In the comparisons between the three groups "well above average", "above average" and "below average", the Kruskal-Wallis test was used, with Dunn's post hoc. P value less than 0.05 was used as a cut-off point for statistical significance.

\section{RESULTS}

Among the 1,314 people with DM registered in the $04 \mathrm{BHU}$ selected for this study, 400 were invited to participate; 329 accepted and 71 refused to participate (claiming lack of time to receive the researchers). Regarding sociodemographic characteristics, it is noteworthy that most participants were between 60 and 69 years old, were female, married, studied from 1 to 5 years old, retired and had a family income of 1 to 3 minimum wages. Table 1 presents the sociodemographic characteristics of the study participants.

Most participants $(63.8 \%)$ use only BHU for health care. The other (36.2\%) use other health services, through agreements and/or individuals, in addition to BHU. It was also found that 98.7\% use BHU at a frequency greater than three times a year for medical consultations (95.7\%), to take medications (97.2\%), to perform/mark complementary exams (82.5\%) and for nursing consultations (33.7\%).

As for clinical characteristics, it was found that most of them have 01 to 05 years of diagnosis for DM (65.6\%) and drug therapy with oral hypoglycemic agents (65.9\%). 
Table 1 - Sociodemographic characteristics of people with diabetes mellitus participating in the study, São José, Santa Catarina, Brazil, 2017

\begin{tabular}{|c|c|c|}
\hline & $\begin{array}{l}\text { Frequencies } \\
\mathbf{N}=329\end{array}$ & n (\%) \\
\hline \multicolumn{3}{|l|}{ Age group } \\
\hline Up to 59 years old & 110 & 33.4 \\
\hline 60-69 years old & 127 & 38.6 \\
\hline 70 years or over & 92 & 28 \\
\hline Total & 329 & 100 \\
\hline \multicolumn{3}{|l|}{ Sex } \\
\hline Male & 93 & 28.3 \\
\hline Female & 236 & 71.7 \\
\hline Total & 329 & 100 \\
\hline \multicolumn{3}{|l|}{ Marital status } \\
\hline Married & 166 & 50.5 \\
\hline Single & 24 & 7.3 \\
\hline Separated/divorced & 57 & 17.3 \\
\hline Widowed & 82 & 24.9 \\
\hline Total & 329 & 100 \\
\hline \multicolumn{3}{|l|}{ Years of education ${ }^{a}$} \\
\hline Never attended school & 27 & 8.3 \\
\hline 1 to 5 years & 159 & 48.6 \\
\hline 6 to 9 years & 56 & 17.1 \\
\hline 10 to 12 years & 54 & 16.5 \\
\hline 13 or more years & 31 & 9.5 \\
\hline Total $^{\mathrm{a}}$ & 327 & 100 \\
\hline \multicolumn{3}{|l|}{ Occupational Status } \\
\hline Active & 87 & 26.4 \\
\hline Under sick leave & 17 & 5.2 \\
\hline Retired & 193 & 58.7 \\
\hline Unemployed & 32 & 9.7 \\
\hline Total & 329 & 100 \\
\hline \multicolumn{3}{|l|}{ Income ${ }^{* b}$} \\
\hline Less than one wage & 9 & 2.8 \\
\hline 1 to 3 wages & 238 & 73.2 \\
\hline 3 to 6 wages & 75 & 23.1 \\
\hline More than 6 wages & 3 & 0.9 \\
\hline Total $^{b}$ & 325 & 100 \\
\hline
\end{tabular}

When comparing the adherence to self-care activities of people with DM assisted by different teams, it was evidenced that those assisted by teams with general performance"well above average" had a higher average in the number of days they followed a healthy diet in the last week, the number of days per week that they followed the dietary guidance given by a health professional, the number of days they underwent blood glucose monitoring as recommended by a health professional, and the use of medications. Foot examination was better in "above average" teams, as shown in Table 2.

With regard to aspects of quality of care in Primary Care associated with adherence to self-care activities, Table 3 compares adherence to self-care activities of people with DM with the coordination of care in the care network and problem solving of FHS teams. Better adherence to a healthy diet, dietary guidance given by a health professional and blood glucose monitoring was evidenced among people with DM assisted by teams better assessed in the coordination of care. Foot examination was better in the "below average" teams, as shown in Table 3.

Table 4 shows that people with DM assisted by teams "well above average" in agenda organization have higher averages in the number of days they followed a healthy diet, in which they performed blood glucose monitoring as recommended by a professional and in taking medications. Foot examination was better in "above average" teams in this sub-dimension.
Table 2 - Comparison of the adherence to self-care activities of people with diabetes mellitus with the overall performance of Family Health Strategy teams, São José, Santa Catarina, Brazil, 2017

\begin{tabular}{|c|c|c|c|c|}
\hline \multirow[b]{2}{*}{ QAD Items } & \multicolumn{3}{|c|}{ Overall team performance } & \multirow[b]{2}{*}{$\begin{array}{c}p \\
\text { value }\end{array}$} \\
\hline & $\begin{array}{c}\text { Median } \\
\text { or below } \\
\text { average } \\
\text { Mean } \\
\text { (SD) }\end{array}$ & $\begin{array}{c}\text { Above } \\
\text { average } \\
\text { Mean } \\
\text { (SD) }\end{array}$ & $\begin{array}{l}\text { Well above } \\
\text { average } \\
\text { Mean } \\
\text { (SD) }\end{array}$ & \\
\hline Followed a healthy diet & $2.95(2.91)^{*}$ & $3.20(3.00)$ & $4.09(2.75)^{*}$ & $0.012^{*}$ \\
\hline $\begin{array}{l}\text { Followed the food } \\
\text { guidance given by a } \\
\text { health professional }\end{array}$ & $2.95(2.91)^{*}$ & $3.20(3.00)$ & $4.08(2.66)^{*}$ & $0.013^{*}$ \\
\hline $\begin{array}{l}\text { Ate five or more fruits } \\
\text { and/or vegetables }\end{array}$ & $4.43(2.50)$ & $4.84(2.67)$ & $4.92(2.58)$ & 0.350 \\
\hline Ate high-fat foods & $2.15(2.73)$ & $2.29(2.75)$ & $1.86(2.43)$ & 0.585 \\
\hline Ate sweets & $2.08(2.52)$ & $2.28(2.58)$ & $1.69(2.06)$ & 0.456 \\
\hline $\begin{array}{l}\text { Performed physical } \\
\text { activity for at least } 30 \mathrm{~min}\end{array}$ & $1.85(2.63)$ & $1.38(2.32)$ & $1.51(2.30)$ & 0.491 \\
\hline $\begin{array}{l}\text { Performed specific } \\
\text { physical exercise }\end{array}$ & $1.36(2.34)$ & $1.07(2.16)$ & $1.53(2.35)$ & 0.225 \\
\hline Rated blood sugar & $1.77(2.60)$ & $2.15(2.97)$ & $2.49(2.95)$ & 0.180 \\
\hline $\begin{array}{l}\text { Rated blood sugar as } \\
\text { recommended by a } \\
\text { professional }\end{array}$ & $1.28(2.22)^{*}$ & $1.66(2.75)$ & $2.48(3.08)^{*}$ & $0.018^{*}$ \\
\hline Examined the feet & $5.85(2.47)$ & $5.98(2.48)^{\#}$ & $4.98(3.01)^{\#}$ & $0.002^{*}$ \\
\hline $\begin{array}{l}\text { Examined the shoes } \\
\text { before wearing them }\end{array}$ & $5.13(3.12)$ & $5.18(3.06)$ & $4.91(3.12)$ & 0.707 \\
\hline $\begin{array}{l}\text { Dried the space between } \\
\text { the toes after cleaning } \\
\text { them }\end{array}$ & $6.13(2.28)$ & $6.06(2.40)$ & $5.91(2.49)$ & 0.760 \\
\hline $\begin{array}{l}\text { Took the medications as } \\
\text { recommended }\end{array}$ & $4.85(3.16)^{*}$ & $5.34(2.82)^{\#}$ & $6.51(1.64)^{* . \#}$ & $<0.001 *$ \\
\hline
\end{tabular}

Note: $Q A D$ - Diabetes Self-Care Activities Questionnaire; ${ }^{*} p<0.05 ;$ Kruskal-Wallis test; ${ }^{*} D u n n ' s$ post hoc (differences between median or below average and well above average); "Dunn's post hoc (differences between above average and well above average).

Table 3 - Comparison of adherence to self-care activities of people with diabetes mellitus with the coordination of care, care network and problem solving of Family Health Strategy teams, São José, Santa Catarina, Brazil, 2017

\begin{tabular}{|c|c|c|c|c|}
\hline \multirow[b]{2}{*}{ QAD Items } & \multicolumn{3}{|c|}{$\begin{array}{l}\text { Team performance in the } \\
\text { coordination of care, care } \\
\text { network and problem solving } \\
\text { subdimension }\end{array}$} & \multirow{2}{*}{$\begin{array}{c}p \\
\text { value }\end{array}$} \\
\hline & $\begin{array}{l}\text { Median } \\
\text { or below } \\
\text { average } \\
\text { Mean } \\
\text { (SD) }\end{array}$ & $\begin{array}{l}\text { Above } \\
\text { average } \\
\text { Mean } \\
\text { (SD) }\end{array}$ & $\begin{array}{l}\text { Well above } \\
\text { average } \\
\text { Mean } \\
\text { (SD) }\end{array}$ & \\
\hline Followed a healthy diet & $2.78(2.88)^{\neq . \epsilon}$ & $3.95(3.00)^{\epsilon}$ & $4.05(2.66)^{*}$ & $0.003^{*}$ \\
\hline $\begin{array}{l}\text { Followed the food } \\
\text { guidance given by a } \\
\text { health professional }\end{array}$ & $2.78(2.88)^{\neq . \epsilon}$ & $3.96(2.86)^{\epsilon}$ & $4.02(2.64)^{*}$ & $0.003^{*}$ \\
\hline $\begin{array}{l}\text { Ate five or more fruits } \\
\text { and/or vegetables }\end{array}$ & $4.52(2.68)$ & $4.70(2.53)$ & $5.09(2.56)$ & 0.183 \\
\hline Ate high-fat foods & $2.32(2.75)$ & $2.19(2.68)$ & $1.67(2.32)$ & 0.270 \\
\hline Ate sweets & $2.20(2.63)$ & $2.08(2.37)$ & $1.58(1.93)$ & 0.463 \\
\hline $\begin{array}{l}\text { Performed physical } \\
\text { activity for at least } 30 \mathrm{~min}\end{array}$ & $1.69(2.54)$ & $1.34(2.08)$ & $1.59(2.46)$ & 0.745 \\
\hline $\begin{array}{l}\text { Performed specific } \\
\text { physical exercise }\end{array}$ & $1.20(2.26)$ & $1.24(2.02)$ & $1.63(2.53)$ & 0.445 \\
\hline
\end{tabular}

To be continued 


\begin{tabular}{|c|c|c|c|c|}
\hline \multirow[b]{2}{*}{ QAD Items } & \multicolumn{3}{|c|}{$\begin{array}{l}\text { Team performance in the } \\
\text { coordination of care, care } \\
\text { network and problem solving } \\
\text { subdimension }\end{array}$} & \multirow{2}{*}{$\begin{array}{c}p \\
\text { value }\end{array}$} \\
\hline & $\begin{array}{l}\text { Median } \\
\text { or below } \\
\text { average } \\
\text { Mean } \\
\text { (SD) }\end{array}$ & $\begin{array}{l}\text { Above } \\
\text { average } \\
\text { Mean } \\
\text { (SD) }\end{array}$ & $\begin{array}{l}\text { Well above } \\
\text { average } \\
\text { Mean } \\
\text { (SD) }\end{array}$ & \\
\hline Rated blood sugar & 1.77 (2.67) & $2.34(3.02)$ & $2.57(2.92)$ & 0.080 \\
\hline $\begin{array}{l}\text { Rated blood sugar as } \\
\text { recommended by a } \\
\text { professional }\end{array}$ & $1.37(2.39)^{*}$ & $1.97(2.96)^{\#}$ & $2.61(3.07)^{¥ . \#}$ & $0.004^{*}$ \\
\hline Examined the feet & $5.95(2.42)^{¥}$ & $5.12(2.99)$ & $5.11(2.93)^{*}$ & $0.049^{*}$ \\
\hline $\begin{array}{l}\text { Examined the shoes } \\
\text { before wearing them }\end{array}$ & $5.08(3.14)$ & 4.90 (3.09) & $5.06(3.09)$ & 0.854 \\
\hline $\begin{array}{l}\text { Dried the space between } \\
\text { the toes after cleaning } \\
\text { them }\end{array}$ & $6.05(2.37)$ & $5.96(2.43)$ & $5.97(2.47)$ & 0.946 \\
\hline $\begin{array}{l}\text { Took the medications as } \\
\text { recommended }\end{array}$ & $5.13(3.01)^{*}$ & $5.83(2.46)$ & $6.53(1.61)^{*}$ & $<0.001^{*}$ \\
\hline
\end{tabular}

Note: $Q A D$ - Diabetes Self-Care Activities Questionnaire; * $p<0.05 ;$ Kruskal-Wallis test; ${ }^{*}$ Dunn's post hoc (differences between median or below average and well above average); ${ }^{\epsilon} D$ unn's post hoc (differences between median or below average and above average); "Dunn's post hoc (differences between above average and well above average).

Table 4 - Comparison of adherence to self-care activities of people with diabetes mellitus with the organization of Family Health Strategy teams' agenda, São José, Santa Catarina, Brazil, 2017

\begin{tabular}{|c|c|c|c|c|}
\hline \multirow[b]{2}{*}{ QAD Items } & \multicolumn{3}{|c|}{$\begin{array}{l}\text { Team performance in the agenda } \\
\text { organization subdimension }\end{array}$} & \multirow[b]{2}{*}{$\begin{array}{c}p \\
\text { value }\end{array}$} \\
\hline & $\begin{array}{l}\text { Median } \\
\text { or below } \\
\text { average } \\
\text { Mean } \\
\text { (SD) }\end{array}$ & $\begin{array}{c}\text { Above } \\
\text { average } \\
\text { Mean } \\
\text { (SD) }\end{array}$ & $\begin{array}{l}\text { Well above } \\
\text { average } \\
\text { Mean } \\
\text { (SD) }\end{array}$ & \\
\hline Followed a healthy diet & $3.20(3.00)$ & $2.67(2.94)^{\# . \epsilon}$ & $4.05(2.66)^{\#}$ & $0.002^{*}$ \\
\hline $\begin{array}{l}\text { Followed the food } \\
\text { guidance given by a } \\
\text { health professional }\end{array}$ & $3.20(3.00)$ & $2.67(2.94)^{\# . \epsilon}$ & $4.02(2.64)^{\#}$ & $0.001 *$ \\
\hline $\begin{array}{l}\text { Ate five or more fruits } \\
\text { and/or vegetables }\end{array}$ & $4.66(2.53)$ & $4.56(2.68)$ & $5.09(2.56)$ & 0.188 \\
\hline Ate high-fat foods & $1.95(2.57)$ & $2.60(2.84)$ & $1.67(2.32)$ & 0.060 \\
\hline Ate sweets & $2.12(2.43)$ & $2.15(2.57)$ & $1.58(1.93)$ & 0.451 \\
\hline $\begin{array}{l}\text { Performed physical } \\
\text { activity for at least } 30 \mathrm{~min}\end{array}$ & $1.43(2.13)$ & $1.59(2.51)$ & $1.59(2.46)$ & 0.995 \\
\hline $\begin{array}{l}\text { Performed specific } \\
\text { physical exercise }\end{array}$ & $1.30(2.03)$ & $1.12(2.25)$ & $1.63(2.53)$ & 0.280 \\
\hline Rated blood sugar & $2.34(2.91)$ & $1.77(2.81)^{\#}$ & $2.57(2.92)^{\#}$ & $0.026^{*}$ \\
\hline $\begin{array}{l}\text { Rated blood sugar as } \\
\text { recommended by a } \\
\text { professional }\end{array}$ & $2.04(2.88)$ & $1.29(2.47)^{\#}$ & $2.61(3.07)^{\#}$ & $0.001 *$ \\
\hline Examined the feet & $5.03(3.01)^{\epsilon}$ & $6.07(2.33)^{\# . \epsilon}$ & $5.11(2.93)^{\#}$ & $0.008^{*}$ \\
\hline $\begin{array}{l}\text { Examined the shoes } \\
\text { before wearing them }\end{array}$ & $4.63(3.21)$ & $5.41(2.95)$ & $5.06(3.09)$ & 0.175 \\
\hline $\begin{array}{l}\text { Dried the space between } \\
\text { the toes after cleaning } \\
\text { them }\end{array}$ & $5.97(2.42)$ & $6.04(2.38)$ & $5.97(2.47)$ & 0.963 \\
\hline
\end{tabular}

Table 4 (concluded)

\begin{tabular}{lcccc}
\hline & \multicolumn{3}{c}{$\begin{array}{c}\text { Team performance in the agenda } \\
\text { organization subdimension }\end{array}$} \\
Median & & & \\
QAD Items & $\begin{array}{c}\text { obove } \\
\text { avelow }\end{array}$ & Well above & $p$ \\
Mean & Merage & average & value \\
& (SD) & (SD) & Mean & \\
& & (SD) & \\
\hline
\end{tabular}

Took the medications as recommended

$5.69(2.60)^{*} \quad 5.29(2.89)^{\#} 6.53(1.61)^{\# . *} \mathbf{0 . 0 0 1 *}$

Note: $Q A D$ - Diabetes Self-Care Activities Questionnaire; ${ }^{*} p<0.05 ;$ Kruskal-Wallis test; ${ }^{*} D u n n ' s$ post hoc (differences between median or below average and well above average): $\epsilon^{\epsilon}$ Dunn's pos hoc (differences between median or below average and above average); "Dunn's post hoc (differences between above average and well above average).

Table 5 - Comparison of adherence to self-care activities of people with diabetes mellitus with the amount and conditions of use of equipment, materials, supplies and printed matter in Basic Health Units, São José, Santa Catarina, Brazil, 2017

\begin{tabular}{|c|c|c|c|c|}
\hline \multirow[b]{2}{*}{ QAD Items } & \multicolumn{3}{|c|}{$\begin{array}{l}\text { Team performance in } \\
\text { the equipment, materials and } \\
\text { supplies subdimension }\end{array}$} & \multirow[b]{2}{*}{$\begin{array}{c}p \\
\text { value }\end{array}$} \\
\hline & $\begin{array}{l}\text { Median } \\
\text { or below } \\
\text { average } \\
\text { Mean } \\
\text { (SD) }\end{array}$ & $\begin{array}{l}\text { Above } \\
\text { average } \\
\text { Mean } \\
\text { (SD) }\end{array}$ & $\begin{array}{l}\text { Well above } \\
\text { average } \\
\text { Mean } \\
\text { (SD) }\end{array}$ & \\
\hline Followed a healthy diet & $2.24(2.80)^{\epsilon: \neq}$ & $3.86(2.79)^{\epsilon}$ & $4.29(2.81)^{*}$ & $<0.001 *$ \\
\hline $\begin{array}{l}\text { Followed the food } \\
\text { guidance given by a } \\
\text { health professional }\end{array}$ & $2.24(2.80)^{\epsilon . \neq}$ & $3.86(2.77)^{\epsilon}$ & $4.26(2.64)^{*}$ & $<0.001^{*}$ \\
\hline $\begin{array}{l}\text { Ate five or more fruits } \\
\text { and/or vegetables }\end{array}$ & $4.36(2.76)$ & $5.05(2.53)$ & $4.63(2.55)$ & 0.139 \\
\hline Ate high-fat foods & $2.68(2.82)^{\epsilon}$ & $2.25(2.55)$ & $1.66(2.43)^{\epsilon}$ & $0.007^{*}$ \\
\hline Ate sweets & $2.41(2.81)$ & $1.72(2.14)$ & $1.93(2.15)$ & 0.438 \\
\hline $\begin{array}{l}\text { Performed physical } \\
\text { activity for at least } 30 \\
\text { min }\end{array}$ & $1.87(2.70)$ & $1.36(2.30)$ & $1.66(2.24)$ & 0.147 \\
\hline $\begin{array}{l}\text { Performed specific } \\
\text { physical exercise }\end{array}$ & $1.27(2.45)$ & $1.30(2.29)$ & $1.64(2.23)$ & 0.119 \\
\hline Rated blood sugar & $1.78(2.79)$ & $2.34(2.90)$ & $2.50(2.95)$ & 0.160 \\
\hline $\begin{array}{l}\text { Rated blood sugar as } \\
\text { recommended by a } \\
\text { professional }\end{array}$ & $1.31(2.47)$ & $2.18(2.90)$ & $2.36(3.10)$ & 0.051 \\
\hline Examined the feet & $5.89(2.50)^{¥}$ & $5.64(2.64)^{\#}$ & $4.98(3.21)^{\text {\#.\# }}$ & $<0.001^{*}$ \\
\hline $\begin{array}{l}\text { Examined the shoes } \\
\text { before wearing them }\end{array}$ & $5.00(3.18)$ & $5.12(3.07)$ & $4.82(3.10)$ & 0.670 \\
\hline $\begin{array}{l}\text { Dried the space between } \\
\text { the toes after cleaning } \\
\text { them }\end{array}$ & $5.75(2.66)$ & $6.03(2.40)$ & $6.08(2.29)$ & 0.665 \\
\hline $\begin{array}{l}\text { Took the medications as } \\
\text { recommended }\end{array}$ & $4.97(3.05)^{€ . \neq}$ & $5.97(2.38)^{\epsilon}$ & $6.49(1.61)^{*}$ & $0.003^{*}$ \\
\hline
\end{tabular}

Note: QAD - Diabetes Self-Care Activities Questionnaire; ${ }^{*} p<0.05 ;$ Kruskal-Wallis test; ${ }^{*}$ Dunn's post hoc (differences between median or below average and well above average); ${ }^{\epsilon} D u n n ' s$ post hoc (differences between median or below average and above average); "Dunn's post hoc (differences between above average and well above average).

Adherence to self-care activities among people with DM was compared with the quantity and conditions of use of equipment, materials, supplies and printed matter at BHU. People with DM attended by teams "well above average" in this sub-dimension had better adherence to the diet, better adherence to dietary 
guidance given by a health professional, less consumption of foods rich in fats and better adherence to the use of medications. Foot examination was better in the "below average" and "above average" teams in this subdimension, as shown in Table 5.

In the medications that comprise the basic pharmacy subdimension, all teams were classified as "well above average", therefore no comparisons were established.

\section{DISCUSSION}

The predominance of women, retired, with low education and income evidenced in this study is a common profile among people seeking care in Primary Care in Brazil. Data described in literature demonstrate that DM is more diagnosed in women ${ }^{(14)}$. This fact is due to the care that women have in seeking health services more frequently ${ }^{(15)}$ and also to the higher prevalence of DM among women in the Brazilian population ${ }^{(2,14,16)}$.

The low education and income found causes people to have a strong dependence on the public health system, especially Primary Care ${ }^{(17-18)}$, which is also evidenced by the fact that most participants use only BHU for their health care.

The best adherence to a healthy diet, blood glucose monitoring as recommended by a professional and the use of medications among people with DM assisted by teams with better overall performance demonstrates a reflection of quality of care in important dimensions of self-care. Nevertheless, less desirable diet and blood glucose monitoring were found in all teams. Other studies have identified low adherence to a healthy diet ${ }^{(19)}$ and blood glucose monitoring ${ }^{(20)}$. In fact, adherence to a healthy diet is one of the most difficult factors from the point of view of people with $\mathrm{DM}^{(15,21)}$ and one of the greatest challenges for FHS teams, due to the complexity that involves eating behavior ${ }^{(19,21)}$. Blood glucose monitoring, in turn, whose importance is indisputable among people with DM who use insulin, has a very debatable frequency, in clinical practice, with regard to care among people with DM who use oral hypoglycemic agents ${ }^{(3)}$, making inferences about this dimension of self-care difficult.

Specifically in relation to better adherence to the diet, glycemic monitoring and medication use among people served by the teams best assessed in coordinating care and agenda organization, some inferences can be made.

Coordinated work involves, among other aspects, that the person is referred for specialized consultation, that there are protocols that guide the prioritization of cases that need referral and that tests are requested ${ }^{(9)}$. The results found reinforce the importance of supporting the promotion and development of organized and coordinated actions that mobilize the internal resources of people with DM for adaptation to the diet plan, glycemic monitoring (aspects that are still fragile in the studied population) and the use of medication.

Agenda organization, in turn, involves a weekly schedule of activities among the professionals who are part of the teams. It includes conducting home visits, community activities and/or health education groups, booking vacancies on the agenda or an easily accessible time for the professional so that users can search and show test results ${ }^{(9)}$. It can be said that these factors can also strengthen adherence to diet, blood glucose monitoring and medication use, as having these individual and/or collective spaces can make people with DM have more contact with the service and greater opportunity to resolution regarding these dimensions of self-care.

This study also showed that, among people with DM attended by teams better evaluated in material equipment and supplies, there was a better adherence to the diet, less consumption of foods rich in fat and better adherence to the use of medications. This sub-dimension of the PMAQ assesses the presence in quantity and conditions of use of equipment, such as a pressure device, anthropometric scale and ruler, stethoscope, syringe, glucometers, among others ${ }^{(9)}$. Literature points out that people with DM who know their health situation find it easier to adhere to self-care ${ }^{(22)}$. Thus, the presence in quantity and conditions of use of this equipment and materials are essential for the person with DM to know their health status and thus have better adherence to self-care activities.

It is worth mentioning that inequalities in access to inputs contribute to the reduction of adherence to self-care, as they contribute to dissatisfaction with the assistance provided and, therefore, result in less motivation to follow treatment ${ }^{(23)}$.

As for the presence of medications that are part of the basic pharmacy, their importance for adherence to drug treatment stands out, which was more desirable in this study. In fact, in a previous study, people who needed to buy drugs had less adherence to drug treatment ${ }^{(17)}$, which emphasizes the importance of free access to the drugs needed for treatment.

Drug treatment is one of the main strategies for controlling DM at the individual level, especially among people with low socioeconomic status ${ }^{(23)}$. However, better pharmacotherapeutic compliance can be achieved when there is a greater bond between person and $\mathrm{BHU}$, as this provides greater opportunity for contact with health professionals ${ }^{(24)}$, which can be achieved through the coordination of care, the organization of the agenda and with appropriate equipment, materials and supplies as already mentioned.

As for foot examination, adherence to this dimension of selfcare was superior to other studies ${ }^{(11,13)}$, being better in teams below average and above average. Despite the inverse relationship between the quality of care and the examination of the feet, desirable means of adherence to this dimension of self-care were evidenced in all teams. It can be inferred that the results of the various studies on foot care are strengthening the behavior of people with DM and the actions of professionals in this regard, reflecting a paradigm shift in this behavior.

It should be noted, however, that literature points out that foot care still has limited attention compared to other DM complications $^{(25)}$. A study with the objective of evaluating the prevalence and factors associated with actions to prevent foot ulcers in people with DM in Brazil identified that the performance of professionals in prevention is considered precarious. In this study, only $33.6 \%$ of people with DM had their feet examined by a health professional ${ }^{(26)}$.

\section{Study limitations}

As for the study limitations, those common to cross-sectional designs and the analysis of self-reported information can be highlighted. The absence of studies with a similar design was also a limiting factor for discussing the results. However, these limitations do not reduce the reliability and relevance of the 
detected associations, but they must be considered when interpreting the results.

\section{Contributions to nursing}

The associations found between adherence to self-care activities with aspects of quality of care in Primary Care have clinical and organizational relevance for the health team. The evidence that a better agenda organization, coordination of care and resolution and better equipment, materials and supplies can improve important dimensions of self-care is directly reflected in the work of the nursing team. Nurses are one of the main modulating agents in the coordination of care and in the organization of FHS teams' agenda. This work brings contributions to these professionals who need to strengthen their practices in order to ensure compliance with these actions.

\section{CONCLUSIONS}

This study showed that adherence to self-care activities among people with DM is associated with the quality of care received in Primary Care. People with DM treated in Primary Care by FHS teams with better overall performance and, specifically, with better agenda organization, better coordination of care and resolution and better equipment, materials and supplies had better adherence to a healthy diet, blood glucose monitoring and medication use. The presence of medications that are part of the basic pharmacy may also have favored adherence to drug treatment. Desirable adherence to foot care was evidenced in people with DM attended by all FHS teams regardless of the quality of care received in Primary Care.

It is worth mentioning that health programs and actions converge in the sense that people with DM achieve self-care. FHS allows access and resolution of health services; the PMAQ assesses the actions provided by FHS teams seeking quality of care in Primary Care; programs guarantee access to basic medications.

Considering the findings, it is recommended that institutional guidelines be strengthened in line with SUS guidelines, ensuring longitudinality, comprehensiveness and coordination of care for people with DM so that they achieve self-care.

\section{FUNDING}

To the Brazilian National Council of Science and Technology (CNPq; PhD scholarship granted for Samara Eliane Rabelo Suplici).

\section{REFERENCES}

1. American Diabetes Association (ADA). Classification and Diagnosis of Diabetes: Standards of Medical Care in Diabetes. Diabetes Care, 2020;43(suppl. 01):S14-S31. https://doi.org/10.2337/dc20-S002

2. Malta DC, Duncan BB, Schmidt MI, Machado IE, Silva AG, Bernal RTI, et al. Prevalence of diabetes mellitus as determined by glycated hemoglobin in the Brazilian adult population, National Health Survey. Rev Bras Epidemiol. 2019;22(suppl. 02):e190006. https://doi.org/10.1590/1980-549720190006

3. American Diabetes Association (ADA). Introduction: Standards of Medical Care in Diabetes-2020. Diabetes Care. 2020;43(suppl. 01):S1-2. https://doi.org/10.2337/dc20-Sint

4. Rincón-Romero MK, Torres-Contreras C, Corredor-Pardo KA. Adherencia terapéutica en personas con diabetes mellitus tipo 2. Rev Cienc Cuid. 2017;14(1):40-59. https://doi.org/10.22463/17949831.806

5. Parra DI, Romero Guevara SL, Rojas LZ. Influential Factors in Adherence to the Therapeutic Regime in Hypertension and Diabetes. Invest Educ Enferm. 2019;37(3). https://doi.org/10.17533/udea.iee.v37n3e02

6. Salci MA, Meirelles BHS, Silva DMGV. Primary care for diabetes mellitus patients from the perspective of the care model for chronic conditions. Rev Latino-Am Enfermagem. 2017;25:e2882. https://doi.org/10.1590/1518-8345.1474.2882

7. Silva LB, Soares SM, Silva PAB, Santos JFG, Miranda LCV, Santos RM. Assessment of the quality of primary care for the elderly according to the Chronic Care Model. Rev Latino-Am Enfermagem. 2018;26:e2987. https://doi.org/10.1590/1518-8345.2331.2987

8. Sousa VD, Driessnack M, Mendes IAC. Revisão dos desenhos de pesquisa relevantes para enfermagem: Parte 1: desenhos de pesquisa quantitativa. Rev Latino-Am Enfermagem. 2007;15(3):502-7. https://doi.org/10.1590/s0104-11692007000300022

9. Ministério da Saúde (BR). Programa Nacional de Melhoria do Acesso e da Qualidade da Atenção Básica (PMAQ): manual instrutivo. Brasília: Ministério da Saúde; 2012.62 p.

10. Nassar SM, Wronscki V, Ohira M. SEstatNet - Sistema Especialista para o Ensino de Estatística na Web [Internet]. UFSC. 2020 [cited 2020 May 4]. Available from: http://sestatnet.ufsc.br

11. Michels MJ, Coral MHC, Sakae TM, Damas TB, Furlanetto LM. Questionário de Atividades de Autocuidado com o Diabetes: tradução, adaptação e avaliação das propriedades psicométricas. Arq Bras Endocrinol Metab. 2010;54(7):644-51. https://doi.org/10.1590/S0004-27302010000700009

12. Batista JMF, Teixeira CRS, Becker TAC, Zanetti ML, Istilli PT, Pace AE. Conhecimento e atividades de autocuidado de pessoas com diabetes mellitus submetidas a apoio telefônico. Rev Eletrôn Enferm. 2017;19:a36. https://doi.org/10.5216/ree.v19.42199

13. Rezende Neta DS, Silva ARV, Silva GRF. Adesão das pessoas com diabetes mellitus ao autocuidado com os pés. Rev Bras Enferm. 2015;68(1):111-6. https://doi.org/10.1590/0034-7167.2015680115p

14. Francisco PMSB, Rodriguez PS, Costa KS, Tavares NUL, Tierling VL, Barros MBA, et al. Prevalência de diabetes em adultos e idosos, uso de medicamentos e fontes de obtenção: uma análise comparativa de 2012 e 2016. Rev Bras Epidemiol. 2019;22:e190061. https://doi. org/10.1590/1980-549720190061 
15. Oliveira LMSM, Souza MFC, Souza LAS, Melo IRC. Adesão ao tratamento dietético e evolução nutricional e clínica de pacientes com diabetes mellitus tipo 2. HU Rev [Internet]. 2016 [cited 2020 Jan 31];42(4):277-82. Available from: http://periodicos.ufff.br/index.php/hurevista/ article/view/2488/903

16. Flor LS, Campos MR. Prevalência de diabetes mellitus e fatores associados na população adulta brasileira: evidências de um inquérito de base populacional. Rev Bras Epidemiol. 2017;20(1):16-29. https://doi.org/10.1590/1980-5497201700010002

17. Lauterte P, Silva DMG, Salci MA, Heidemann I, Romanoski P. Protocolo de enfermagem para o cuidado da pessoa com diabetes mellitus na atenção primária. Rev Enferm UFSM. 2020;10:e72. https://doi.org/10.5902/2179769240638

18. Salci MA, Meirelles BHS, Silva DMVGD. Prevention of chronic complications of diabetes mellitus according to complexity. Rev Bras Enferm. 2017;70(5):996-1003. https://doi.org/10.1590/0034-7167-2016-0080

19. Faria HTG, Santos MA, Arrelias CCA, Rodrigues FFL, Gonela JT, Teixeira CRS, et al. Adherence to diabetes mellitus treatments in Family Health Strategy Units. Rev Esc Enferm USP. 2014;48(2):257-63. https://doi.org/10.1590/S0080-623420140000200009

20. Williams JS, Walker RJ, Smalls BL, Hill R, Egede LE. Patient-Centered care, glycemic control, diabetes self-care, and quality of life in adults with type 2 diabetes. Diabetes Technol Ther. 2016;18(10):644-9. https://doi.org/10.1089/dia.2016.0079

21. Zanetti ML, Arrelias CCA, Franco RC, Santos MA, Rodrigues FFL, Faria HTG. Adherence to nutritional recommendations and sociodemographic variables in patients with diabetes mellitus. Rev Esc Enferm USP. 2015;49(4):0619-25. https://doi.org/10.1590/ S0080-623420150000400012

22. Campos TSP, Silva DMGV, Romanoski PJ, Ferreira C, Rocha FL. Fatores associados à adesão ao tratamento de pessoas com diabetes mellitus assistidos pela atenção primária de saúde. J Health Biol Sci. 2016;4(4):251. https://doi.org/10.12662/2317-3076jhbs.v4i4.1030.p251-256.2016

23. Soares DA, Rodrigues CSC, Pereira DF, Rebouças MO, Oliveira JE, Lima VS. Adesão ao tratamento da Hipertensão e do Diabetes: compreensão de elementos intervenientes segundo usuários de um serviço de atenção primária a saúde. Rev APS [Internet]. 2014 [cited 2020 Jan 31];17(3):311-7. Available from: https://periodicos.ufjf.br/index.php/aps/article/view/15306

24. Osborn CY, Mayberry LS, Kim JM. Medication adherence may be more important than other behaviors for optimizing glycaemic control among low-income adults. J Clin Pharm Ther. 2016;41(3):256-9. https://doi.org/10.1111/jcpt.12360

25. Bus SA, Lavery LA, Monteiro-Soares M, Rasmussen A, Raspovic A, Sacco ICN, et al. Guidelines on the prevention of foot ulcers in persons with diabetes (IWGDF 2019 update). Diabetes Metab Res Rev. 2020;36(1):e3269. https://doi.org/10.1002/dmrr.3269

26. Fernandes FCGM, Santos EGO, Morais JFG, Medeiros LMF, Barbosa IR. O cuidado com os pés e a prevenção da úlcera em pacientes diabéticos no Brasil. Cad Saúde Colet. 2020;28(2):302-10. https://doi.org/10.1590/1414-462×202028020258 